\title{
The Implementation of Literacy of 2013 Curriculum in Al ulum Integrated Islamic Senior High School
}

\author{
Intan Sufiah Batubara \\ Department of English Applied Linguistics \\ Universitas Negeri Medan, Indonesia \\ Intansufiah10@gmail.com
}

\author{
Anni Holila Pulungan \\ Department of English Applied Linguistics \\ Universitas Negeri Medan, Indonesia
}

\author{
Rahmad Husein \\ Department of English Applied Linguistics \\ Universitas Negeri Medan, Indonesia
}

\begin{abstract}
In 2013 curriculum, literacy is not only about reading and writing in academic term, but also apply and develop what students read and write into their social life. Moreover, literacy also assists students' character development and gain their humanity aspect. The aims of this study to find out the implementation of literacy in Al Ulum Integrated Islamic Senior High School as the sample of school which really applies literacy based on target of 2013 curriculum specifically in the teachinglearning process. Literacy is a gateway to learning. Through rich literacy programs, students discover the links among reading, writing, thinking, and knowing. It entails at least a tacit awareness of the relationships between textual conventions and their context of use and, ideally, the ability to reflect critically on those relationships. As many qualitative studies, this research has the limitation of phenomenon observed. Literacy dicussed in this research will focus on the language teaching-learning process of Al Ulum Integrated Islamic Senior High School. as a result will make a right follow up for applying curriculum which is going to be used to make teaching learning process run effectively based on the 2013 curriculum.
\end{abstract}

Keywords-2013 Curriculum, Literacy, language teachinglearning process

\section{INTRODUCTION}

The development of civilization in 21 st century requires different point of view in education. The rapid development of information and technology cannot be anticipated by by blocking its benefits in education. While science and knowledge are easier to be transferred through technology and the development is hardly prevented.

Meanwhile the development of civilization is a distinctive challenge for teachers to prepare the excellent human resources and create the winner in global competition. Therefore, the curriculum requires an improvement after an evaluation. As a result, the improvement and the implementation of curriculum need to be conducted to set up the students with the competences needed by the students in facing 21 st century. As changes occur, the minister education and culture, Mohammad Nuh has made new changes to the curriculum called the 2013 curriculum. [1]There are two objective reasons why the minister intended to change to the existing curriculum.

First, preparation the Golden Generation Indonesia for a hundred years of independent Indonesia. Entering a hundred years of Indonesian independence (2045), the population of present students would have aged 35 - 44 years and $45-54$ years. This group is a group of people that are in the reproductive age and is a prospective leaders. Because it is a strategic age group, they should be prepared as early as possible.

The second reason is the preparation of Indonesia's ability to deal with the problems associated with globalization. The existence of the 2013 curriculum becomes a great attention and leads to controversy for most people, because some people regard the 2013 curriculum is not ready to implement. However, the curriculum change especially the 2013 curriculum is purposed to reach better education system.

This curriculum offers some progress from the former curriculum. For example, the 2013 curriculum gives some strategies for teachers and students. Teachers will be more creative, while students will be more active.

In the 2013 curriculum, literacy is also one of important targets to be achieved. Culturally Indonesian society does not have a high literacy culture.

Indonesia has experienced an emergency literacy rate. Therefore, in this the 2013 curriculum, the culture of literacy must be forced and accustomed to become the culture. This literacy culture will affect the quality of education and human resources that are produced

The researcher had conducted a preliminary observation to investigate the implementation of literacy in the observing school names Al Ulum Integrated Islamic Senior High School. After having the preliminary observation, the researcher found that this school has conducting 2013 curriculum since it had been launched by the government in 2014. However, 2013 curriculum was not really implemented because at that time, the principal and and the teachers had not get any training about 2013 curriculum. The school just implemented 2013 curriculum because it was pointed as the sample private school out of some private schools under a state school as main school. 
Moreover, this school really implemented 2013 curriculum in 2016 after it has been revised and the teachers have got some trainings of 2013 curriculum. And at that time also, there had been many schools implemented curriculum 2013.

As a matter of fact, literacy has been implemented in all education institution in Indonesia. However, it only concerns to the basic sense of literacy namely reading and writing. And it is also implemented in Al Ulum Integrated Islamic Senior High School by reading Qur"an every morning before the teaching-learning process is conducted. It has been stated before, it was just about reading.

In 2013 curriculum, literacy is not only about reading and writing in academic term, but also apply and develop what students read and write into their social life. Moreover, literacy also assists students ${ }^{\text {ee }}$ character development and gain their humanity aspect.

In the preliminary observation conducted by the researcher also, literacy also has been implemented in the school environment by providing some slogans and motto. Of course in this case, literacy can be implemented by the supporting facilities available.

Therefore, the researcher wants to find out more and detail about the implementation of literacy in Al Ulum Integrated Islamic Senior High School as the sample of school which really applies literacy based on target of 2013. curriculum specifically in the teaching-learning process.

\section{LITERATURE STUDY}

Curriculum as the foundation of teaching and learning process covers subject matters and students ${ }^{\text {ee learning }}$ experience from inside and outside of school.Curriculum in Indonesia refers to a set of planning and organization of aim, content, and learning material as the guidance to learning activity to achieve a particular educational objective (Republic of Indonesia law, no.20 year 2003).

The 2013 curriculum are curricula for primary and secondary education. In the Indonesian context of education, the primary education consists of primary or elementary school called Sekolah Dasar (SD) and junior secondary school called Sekolah Menengah Pertama (SMP). Secondary Education consists of General Secondary School called Sekolah Menengah Atas (SMA) and Vocational Secondary School called Sekolah Menengah Kejuruan (SMK). At present, the idea of the 2013 curriculum is also being used for the development of Childhood Education (PAUD) and Higher Education (university, D3 and D4) curricula. This.

The implementation of the 2013 curriculum on learning activity in schools by the teachers is implemented in three dimensions, those are teaching learning planning, teaching and learning process, and learning evaluation.

1. Dimension of Teaching Learning Planning

In this dimension, teacher outlines the vision and mission or learning objectives to be achieved. The attempt which should be done is considering all the things which are needed and used in the study in order to achieve the wanted goal. Everything is covered in the lesson plan.

\section{Dimension of Teaching Learning Process}

Learning is a process of interaction between students and students and between students and teachers with learning resources in a learning environment. The characteristics of an ideal learning are interactive and inspiring; fun, challenging, and motivating learners to actively participate; contextual and collaborative; providing enough space for innovation, creativity, and independence of learners; and in accordance with their talents, interests, abilities, and physical and psychological development of learners. Etymologically, literacy comes from Latin „littera "eans letter. Literacy is the mastery of writing system and its conventions. [2] Literacy comprehensively as follows:

"Literacy is the use of socially-, and historically-, and culturally situated practices of creating and interpreting meaning through texts. It entails at least a tacit awareness of the relationships between textual conventions and their context of use and, ideally, the ability to reflect critically on those relationships. Because it is purpose-sensitive, literacy is dynamic - not static - and variable across and within discourse communities and cultures. It draws on a wide range of cognitive abilities, on knowledge of written and spoken language, on knowledge of genres, and on cultural knowledge."

Literacy is a gateway to learning. Through rich literacy programs, students discover the links among reading, writing, thinking, and knowing. They learn to engage with new ideas as they read, write, and talk about a broad range of themes, topics, experiences, and perspectives in a multimedia, multicultural world. Students acquire insight into their own thoughts and growing literacy expertise from purposeful teaching that immerses them in printed, visual, and electronic texts and guides them to make personal connections to the texts they read and write.

Within Curriculum for Excellence, literacy is defined as: "the set of skills which allows an individual to engage fully in society and in learning, through the different forms of language, and the range of texts, which society values and finds useful."

The literacy experiences and outcomes promote the development of skills in using language, particularly those that are used regularly by everyone in their everyday lives. These include the ability to apply knowledge about language. They reflect the need for young people to be able to communicate effectively both face-to-face and in writing through an increasing range of media. They take account of national and international research and of other skills frameworks.

Based on concept, literacy is more than reading and writing. However, it covers thinking skill by using knowledge sources of printing, visual, digital, and auditory. The skill is caled informational literacy. [3]The components of literacy as follows: 


\section{a. Early Literacy}

This component is the skills of listening, understanding oral language, and communicating through picture formed by social interaction specifically basic social namely home. The experience of students in communicating by using the mother tongue is an important foundation to develop the basic literacy which is the next component after early literacy.

b. Basic Literacy

This component is the skills of listening, speaking, reading, writing and counting which leads to the skills of calculating analysis, perceiving, communicating, and describing information based on the personal comprehension and summarizing.

\section{c. Library Literacy}

This component of literacy provide the comprehension of distinguishing between fiction and non fiction, using reference, understanding Dewey Decimal System as the knowledge classification which facilitates the using of library, catalog and index, so that the students will have knowledge about how to comprehend an information comprehensively.

d. Media Literacy

This component is a skill to recognize any kind of media such as printed media, electronic media (radio and television), digital media (internet) and understanding the objectives of their use.

\section{e. Technology Literacy}

This component is the skill to understand the technology such as hardware and software as well as the manners in using the technology. Moreover, the skill to understand the technology are included printing, presenting, and internet access. Practically, computer literacy also applies technology literacy such as shutting up and down the computer, saving and data organizing, and also operating the software. Dealt with the development of technology, this component of literacy is very important to mastered by the students.

f. Visual Literacy

This component ia an advance skill between the media literacy and technology literacy which develops the skill and learning needs by exploring the visual and audio visual materials critically and wisely.

In mastering those components of literacy, participation and support from some people are required. It can be seen from the following table.

\begin{tabular}{|c|c|c|}
\hline No. & $\begin{array}{c}\text { Components of } \\
\text { Literacy }\end{array}$ & Supporting People \\
\hline 1. & Early Literacy & $\begin{array}{c}\text { Parents and family, teacher, } \\
\text { nurse }\end{array}$ \\
\hline 2. & Basic Literacy & Formal Education \\
\hline 3. & Library Literacy & Formal Education \\
\hline 4. & Technology Literacy & $\begin{array}{l}\text { Formal Education and } \\
\text { Family }\end{array}$ \\
\hline 5. & Media Literacy & $\begin{array}{l}\text { Formal Education, Family } \\
\text { and society }\end{array}$ \\
\hline 6. & Visual Literacy & $\begin{array}{l}\text { Formal Education, Family } \\
\text { and society }\end{array}$ \\
\hline
\end{tabular}

\section{METHODOLOGY}

This research uses descriptive qualitative method since main objective is to describe the implementation of the 2013 curriculum in the classes. The research is a qualitative research. According to Banister et al, "Qualitative research is: (a) an attempt to capture the sense that lies within, and that structures what we say about what we do; (b) an exploration, elaboration and systematization of the significance of an identified phenomenon; (c) the illuminative representation of the meaning of a delimited issued or problem."

Moreover, this qualitative research is a case study. [4]" $\mathrm{A}$ case study is an exploration of a "bounded system" or a case (or multiple cases) over time through detailed, indepth data collection involving multiple sources of information rich in context. Case study research is a qualitative research approach in which the investigator explore a bounded system (a case) or multiple boundedsystems (cases) over time through detailed, in-depth data collection involving multiple source information (e.g.,observations, interviews, audiovisual material, and documents and reports), and reports a case description and case-based themes."

In a qualitative research type, the terms "population" and "sample" are unknown, but the term to be used is "setting". The setting of this research is at Al Ulum Integrated Islamic Senior High School Medan. Al Ulum Integrated Islamic Senior High School Medan is one of senior high schools in Medan which has implemented the 2013 curriculum since the 2013 curriculum was launched. And the research will be conducted in School Year 2018/2019 in the first semester.

The instrument in collecting data in this research is observation. Here, the researcher as the key of instrument will show her very important role. In qualitative, there are two types of observation. They are objective description and reflective description. Objective description describes the phenomenon as it happens and naturally without giving any interpretation or opinion. The researcher just let the phenomenon happens naturally. While reflective description is a description by having interpretation or opinion of the researcher. In this research, the researcher concerned to the second type of observation that is reflective description.

In the observation, the researcher will observe how literacy of the 2013 curriculum is implemented in English teachinglearing process. Moreover, the researcher will observe the school environment to find out whether literacy of the 2013 curriculum has been implemented.

Another instrument of this research is interview. In this case, the subject interviewed is the teacher and the school principal. Interview is conducted to get more information about the implementation of literacy in the terms of language learning and school environment. Moreover, interview is also applied to find out the obstacles in implementing literacy of 2013 curriculum.

\section{RESEARCH FINDING}

After analyzing the data, the researcher obtained some findings due to the implementation of literacy of 2013 
curriculum in the teaching-learning process of $\mathrm{Al}$ Ulum Integrated Islamic Senior High School. The implementation of literacy at school is conducted through three processes namely conditioning, developing and learning.

For conditioning, the independent reading of non-textbook for 15 minutes is conducted before the teaching-learning process started. The activity sometimes is changed with reading aloud by the teacher or students in applying storytelling. In this case, listening skill and speaking skill are applied. This conditioning process has been conducted more seriously in this semester and it has run for three months and still consistently conducted by the teachers.

For developing and learning processes in the teachinglearning process, the teacher applies a strategy to enhance students $s^{\text {ee }}$ proficiency in reading namely Model Literature Based. This strategy is applied in activating reading programs The strategy is applied in three activities namely Teacher Directed Activities (Lesson Strategy); Students-Teacher Conference (Text Comprehension); and Approaches for Developing Interest in Reading.

\section{CONCLUSION}

The 2013 curriculum has got many targets dealt with its goal which is better education for creating golden generation for golden Indonesia in 2045. However, this research is only going to focus to the term of "literacy"; one target to be achieved in 2013 curriculum.
Literacy dicussed in this research will focus on the language teaching-learning process of Al Ulum Integrated Islamic Senior High School. The implementation of literacy will also be observed in school environment.

In addition, this research will also concern to the obstacles discovered in implementing literacy of the 2013 curriculum in Al Ulum Integrated Islamic Senior High School.

\section{REFERENCES}

[1] D.A.Katuuk, Manajemen Implementasi Kurikulum: Strategi Penguatan Implementasi Kurikulum 2013. Cakrawala Pendidikan. 2014 Vol. 1 No. 1

[2] R. Kern, Literacy and Language Teaching. Oxford: Oxford University Press. 2000

[3] M.M. Clay, Change over time in children's literacy development. Portsmouth, NH: Heinemann.2001

[4] J.W. Creswell, Research Design: Qualitative, Quantitative and Mixed Methods Approaches (4th ed.). Thousand Oaks, CA: Sage.2014

[5] C. S. Beers, A Principal's Guide to Literacy Instruction. North Carolina: Guilford Press .2009

[6] P. F. Oliva, Developing The Curriculum. Canada: Little, Brown \& Company, 1982), 1982. p. 10.

[7] W. Sanjaya, Kurikulum dan Pembelajaran; Teori dan Praktik Pengembangan KTSP. Jakarta: Prenadamedia Group. 2008.

[8] Sugihartono, Psikologi Pendidikan. Yogyakarta: UNY Press. 2007 